\title{
COVID-19: The Challenges and Opportunities for Water, Air, Agriculture and Energy Sectors
}

\author{
Muhammad Usman $^{1 *}$, Muhammad Farooq ${ }^{2}$, Salah Jellali ${ }^{1}$, Muhammad Farooq ${ }^{3}$, Yassine Charabi ${ }^{4}$, Abdullah M. Al- \\ Sadi $^{3}$ and Abdullah Al-Badi ${ }^{1,5}$ \\ ${ }^{1}$ PEIE Research Chair for the Development of Industrial Estates and Free Zones, Center for Environmental Studies and \\ Research, Sultan Qaboos University, Al-Khoud 123, Muscat, Oman \\ ${ }^{2}$ Department of Clinical Sciences, College of Veterinary and Animal Sciences, Jhang, University of Veterinary and Animal \\ Sciences, Lahore, Pakistan \\ ${ }^{3}$ Department of Plant Sciences, Sultan Qaboos University, Al-Khoud 123, Muscat, Oman \\ ${ }^{4}$ Center for Environmental Studies and Research, Sultan Qaboos University, Al-Khoud 123, Muscat, Oman \\ ${ }^{5}$ Department of Electrical \& Computer Engineering, College of Engineering, Sultan Qaboos University, Al-Khoud 123, Muscat, \\ Oman
}

*For correspondence: muhammad.usman@squ.edu.om

Received 23 January 2021; Accepted 15 February 2021; Published 16.April 2021

\begin{abstract}
Here, we evaluate the COVID-19 associated challenges and opportunities surrounding the water, air, agriculture and energy sectors, the four major elements to sustain life on earth with strong implications on food security and the environment. During this pandemic, significant improvements in the quality of air and water resources have been noted. The tracking of SARS-CoV2, the etiologic agent of COVID-19, in wastewater allowed wastewater-based epidemiology for this disease. However, the presence of SARS-CoV-2 in wastewater and the increased use of antimicrobials for personal hygiene and environmental disinfection can have serious consequences on the environment and public health. Air pollutants and greenhouse gases have been significantly reduced except for ozone that increased due to the decline in $\mathrm{NO}_{\mathrm{x}}$. Tackling air pollution is important due to its role in spreading and worsening the COVID-19. Similarly, this pandemic has a strong impact on crop production systems, livestock industry, food supply chain and global food security. The zoonotic nature of this disease could change human interactions with wildlife and companion animals, but clear strategies are needed to safeguard both human health and biodiversity throughout the COVID-19 recovery. Owing to the advantages of renewable energy highlighted during COVID-19, suitable investments should be dedicated to cleaner and sustainable energy infrastructure in revival plans. (C) 2021 Friends Science Publishers
\end{abstract}

Keywords: COVID-19; Wastewater and surface water; Air and climate change; Agriculture; Livestock; Energy

\section{Introduction}

The ongoing pandemic of the coronavirus disease 2019 (COVID-19) is a major global health crisis with unprecedented impacts on the economy, society, environment, and sustainable development. This disease was first reported in Wuhan, China in December 2019. Approximately three months later (on March $11^{\text {th }}, 2020$ ), the World Health Organization (WHO) declared this a public health emergency of international concern on January $30^{\text {th }}$, 2020. This has been the sixth global health emergency after Ebola (two outbreaks), Zika, polio and swine flu (WHO 2020). Marking six months of this emergency on July $30^{\text {th }}$, 2020, WHO stated that COVID-19 is easily the most severe global health emergency ever declared by the WHO (WHO 2020). At the time of writing, this pandemic is affecting 213 countries/territories leading to over 107 million infected people, more than 2.3 million deaths, sending billions of people into lockdowns (Worldometers 2020). For the moment, this disease does not have any universal treatment and vaccine. After successfully slowing the outbreak, many countries across the world are experiencing resurgence in COVID-19 cases building as the second wave of the virus.

The extent of the pandemic and its eventual impacts are uncertain. Therefore, necessary counter measures to this pandemic and the resulting disruption or decline in demand for services and products will likely to remain in place for months. Governments are responding at local, national, regional and global levels in the face of an evolving body of evidence and other circumstances. For that, authorities and scientific community are seeking emergent insights to tackle this pandemic with an emphasis on saving lives. In addition

To cite this paper: Usman M, M Farooq, S Jellali, M Farooq, Y Charabi, AM Al-Sadi, A Al-Badi (2021). COVID-19: the challenges and opportunities for water, air, agriculture and energy sectors. Intl J Agric Biol 25:1085-1095 
to the immediate health impacts, governments and policy makers should also consider the effects of this pandemic on other sectors for an effective response to this crisis.

Water, air, agriculture, and energy sectors are the four major elements that play a central role to sustain life on earth (Vasel-Be-Hagh and Ting 2020). This manuscript is intended to provide insights into the implications of COVID-19 in these sectors (Fig. 1). COVID-19 has posed severe challenges to these sectors while opening new research avenues and opportunities. Here, we critically evaluate the implications of this crisis for water resources, air pollution, crop production and food security, pets, wild animals and livestock, and energy industry worldwide. Provided below is a brief description of the challenges and opportunities posed by COVID-19 in the water, air, agriculture and energy sectors. A better understanding of the implications of COVID-19 in these sectors will provide useful insights to the researchers, policy makers and governments. These implications should be considered in COVID-19 response policy to avoid the secondary crisis to the health and environment.

\section{COVID-19 and water sector}

COVID-19 and improved water quality: Significant improvements in the quality of water resources (surface as well as ground water) have been reported amid COVID-19 due to strict lockdown measures. For example, Yunus et al. (2020) used remote sensing to assess the impact of the lockdown on the quality of the Vembanad Lake, the longest freshwater lake in India. They noted a significant decline (by about $10-36 \%$ ) in the suspended particulate matter (SPM) of the lake due to the lockdown. Moreover, the time-based analysis of the satellite images from April 2013 to April 2020 highlighted the lowest SPM contents in April 2020 for 11 out of the 20 zones of the studied lake. When compared with these past years, the percentage decrease in SPM for April 2020 is up to $34 \%$ from the previous minima. Patel $e t$ al. (2020b) analyzed the effect of the lockdown on the Yamuna river (stretched within Delhi). On the basis of physico-chemical measurements in nine monitoring stations, they reported that the measured biological oxygen demand (BOD) and chemical oxygen demand (COD) average values decreased by about 43 and $39 \%$, respectively as compared to the pre-lockdown phase. Moreover, the exploitation of satellite images before and during the lockdown showed a marked drop in the estimated turbidity and SPM contents.

A similar trend has been also reported in Italy for Venice lagoon (Braga et al. 2020). Indeed, the comparative analysis of high-resolution satellite images before and during the lockdown witnessed a decrease in turbidity in the airportcity route and the airport water terminal. At these locations, the estimated turbidity values decreased to about 5 NTU which is similar to the values normally found in the lagoon areas around the city. Mandal and Pal (2020) explored the impact of halting stone quarrying and crushing activities in the middle catchment of the Dwarka river basin (eastern India) on the quality of adjacent rivers water and other environmental components. They found that the interruption of the dust release improved the water quality. Indeed, the average $\mathrm{pH}$ and dissolved oxygen values of four selected clusters have decreased from 8.8 to 7.2 and increased from 3.2 to $4.0 \mathrm{mg} \mathrm{L}^{-1}$, respectively. The effect was particularly prominent for total dissolved solids contents which were reduced (from $2382.5 \mathrm{mg} \mathrm{L}^{-1}$ ) by a factor of about 2.2 (Mandal and Pal 2020).

In addition to the effects on surface water quality, the impact of the lockdown on groundwater quality has also been evaluated (Selvam et al. 2020). Changes in physicochemical and biological characteristics of groundwater samples have been recorded at 11 locations in the coastal industrial city of Tuticorin (south India). Due to the minimal agricultural and industrial activities, the concentrations of $\mathrm{NO}_{3}$ in groundwater decreased from $35-98 \mathrm{mg} \mathrm{L}^{-1}$ (before the lockdown) to $20-42 \mathrm{mg} \mathrm{L}^{-1}$ (during the lockdown). In addition, the contents of toxic metals (average of the 11 locations) also decreased. The highest decrease percentages were observed for $\mathrm{Cd}, \mathrm{Pb}, \mathrm{As}$ and $\mathrm{Fe}$ with values of 50, 50, 51 and $60 \%$, respectively. Concerning the biological parameters, the authors reported an average decrease in percentages of fecal coliforms and total coliforms of 48 and $52 \%$, respectively. However, due to the low common groundwater velocities (several $\mathrm{cm} /$ day), these results have to be confirmed through a deeper analysis of: i) pollutants contents variation according to the distance between the sampled wells and industries, ii) the possible dilution effect due to the important observed rainfalls during the lockdown period compared to previous years (Patni and Jindal 2020). It should be noted that lockdown measures declined water consumption in the public, industrial, and commercial categories while increasing it in the residential category (Kalbusch et al. 2020).

As the lockdown measures being eased, industries are resuming their activities with the same associated pollution risks of the water resources observed before the COVID-19 pandemic. It is therefore very important to stimulate the sustainable and eco-friendly management of the produced solid and liquid wastes by the concerned economic sectors. At the same time, the active engagement of stakeholders and the updating of the existing water-related-laws have to be urgently promoted (Hallema et al. 2020). Moreover, the safety of stagnant water in unused buildings, that may harbor pathogens and toxic metals (leaching out of pipes), should also be considered in reopening policy to avoid a secondary health crisis (Viglione 2020).

\section{SARS-CoV-2 in wastewater and its implications}

Recent research has demonstrated that COVID-19 infected people, even those who do not develop symptoms, discharge its causative virus (SARS-CoV-2) through their excrement (Medema et al. 2020). Therefore, researchers in many 


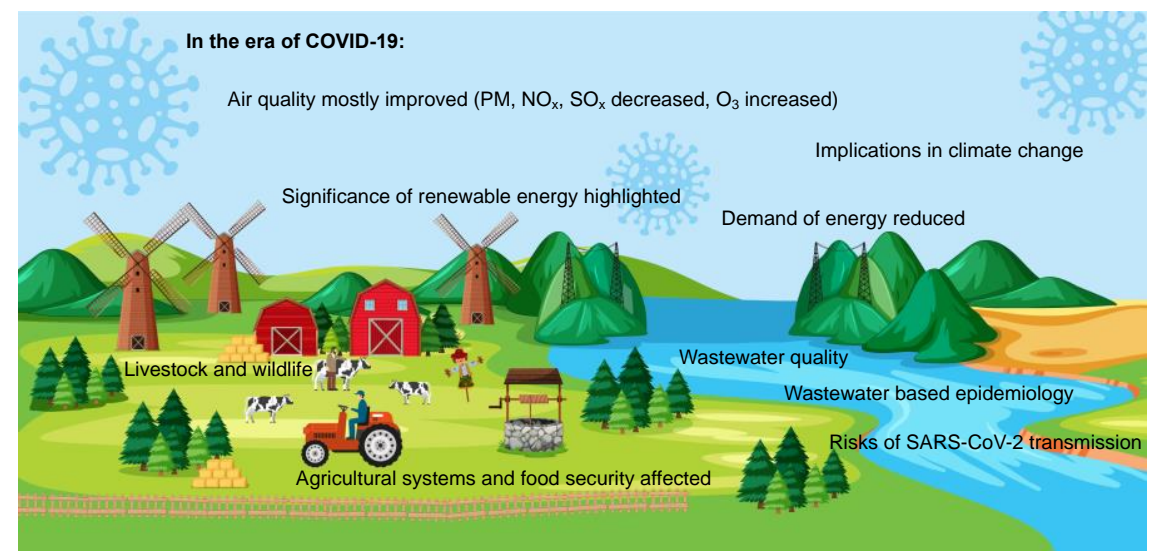

Fig. 1: Major implications of COVID-19 on water, air, agriculture and energy sectors

countries are analyzing the municipal wastewater for SARS$\mathrm{CoV}-2$ virus to track the prevalence of infection (Bivins et al. 2020). After its first detection in wastewater in the Netherlands (Lodder and Husman 2020), SARS-CoV-2 has been identified in wastewater in many countries such as Australia (Ahmed et al. 2020), France (Wurtzer et al. 2020), Germany (Westhaus et al. 2021), Italy ( Rosa et al. 2020), U.S.A. (Wu et al. 2020b), etc. Moreover, people excrete this virus early in the progression of the disease, well before they develop symptoms, which allows the detection of this virus in untreated wastewater before the clinical confirmations (Medema et al. 2020). Therefore, tracking wastewater could serve as an early warning tool and complementary approach for authorities to track the prevalence of infection (Ahmed et al. 2020; Bivins et al. 2020; Rosa et al. 2020; Lodder and Husman 2020; Wu et al. 2020a; Wurtzer et al. 2020; Westhaus et al. 2021). Collection and interpretation of data for wastewater surveillance is an emerging field and therefore can be challenging. For this, it would be essential to set minimum criteria for sampling locations, establish sampling harmonization, develop laboratory analysis methods, quality control to ensure cross laboratory comparability, and collaborate internationally (Bivins et al. 2020; O'Reilly et al. 2020).

However, the existence of SARS-CoV-2 in wastewater and that too in high titers, can have potential health risks (Kitajima et al. 2020; Quilliam et al. 2020). Although there is currently no evidence of SARS-CoV-2 transmission via exposure to wastewater, it remains a significant possibility particularly in developing communities with weak water and wastewater infrastructure (Usman et al. 2020b). Similarly, researchers have also raised concerns about the environmental transmission of SARS-CoV-2 in recreational water (Cahill and Morris 2020), river water (GuerreroLatorre et al. 2020). Similarly, the transmission of this virus remains a significant possibility when virus-laden aerosols are formed such as during toilet flushing, wastewater treatment and sprinkler irrigation (Bogler et al. 2020; Usman et al. 2021). A quantitative microbial risk assessment (QMRA) of this virus was performed for workers at wastewater treatment plants (WWTPs) for three COVID-19 scenarios (moderate, aggressive and extreme) (Zaneti et al. 2021). In the latter two scenarios, the probability of infection to workers was above the tolerable infection risks. This situation highlights the necessity to integrate the safety of wastewater management, recreational water environments, and drinking water supply in the fight against the virus. Moreover, the health of workers at sanitation treatment facilities should also be protected by following the best safety practices. Research is needed regarding the persistence, transmission, and fate of SARS-CoV-2 in wastewater and the environment to better understand its implications in public health and ecology. Considering the concerns about the fecal-oral transmission of SARS-CoV-2, wastewater disinfection has gained significant importance (Huraimel et al. 2020; Kitajima et al. 2020; Usman et al. 2020b). However, disinfectant residues and disinfection byproducts could threaten the aquatic ecosystem due to their ecotoxicological effects (Luan et al. 2020) (as highlighted in Section 2.3).

\section{Increased use of antimicrobials amid COVID-19 is threatening water quality and antimicrobial resistance}

Researchers have been raising concerns regarding the impact of COVID-19 in the propagation of the antimicrobial resistance (AMR) in acute care settings (Rawson et al. 2020a) and the environment (Usman et al. 2020a). It has been reported that the use of broad-spectrum antimicrobials is high despite low bacterial and fungal co-infection in COVID-19 patients (Rawson et al. 2020b). Another potential concern in this context is the increasing use of nontherapeutic antimicrobials for personal hygiene and environmental disinfection, particularly in non-health-care settings (Usman et al. 2020b). Biocides in these antimicrobial products are not eliminated by existing wastewater treatment techniques (Kümmerer et al. 2018) and thus, they are frequently detected in the aquatic environments (Patel et al. 2019). Low-level exposure to these antimicrobial agents can stimulate AMR in the environment posing risks to 
the exposed populations (Usman et al. 2020a). Moreover, the existence of these biocides could disrupt the wastewater treatment processes relying on microbial activity (Luan et al. 2020; McNamara et al. 2014). Therefore, COVID-19 has broader implications in inducing AMR and increasing pharmaceutical contamination in the environment. For this, the impact of both therapeutic and non-therapeutic antimicrobials should be evaluated to better understand the implications of COVID-19 (Race et al. 2020; Usman et al. 2020a). Moreover, investments into effective wastewater treatment are called for as most of the traditional treatment systems are not designed to remove emerging environmental pollutants i.e., pharmaceuticals and personal care products.

\section{COVID-19 and air quality}

COVID-19 has influenced human society at large, including health, economic systems and human relationships. An unforeseen regional effect has resulted from an international reaction involving business activities closures and social distancing. While the severe health consequences of COVID-19 remain a key concern, the pandemic may affect other factors such as the risks of air pollution on health, but this remains unclear (Berman and Ebisu 2020). Exposure to air pollution is a major risk factor for cardiovascular and respiratory diseases (Burnett $e t$ al. 2018). Understanding the extent to which severe behavioral disruptions caused by COVID-19 impacts air pollution is a key tool for health and air pollution control. A decline in anthropogenic air pollution in countries reacting to COVID 19 has been reported in early assessments as highlighted below.

The satellite-derived levels of nitrogen dioxide $\left(\mathrm{NO}_{2}\right)$ in eastern and central China detected by NASA Earth Observatory at the beginning of 2020 were $10-30 \%$ lower than those in 2019 (Vettore 2020). Due to the COVID-19 pandemic outbreak in Wuhan, Chinese authorities stopped transportation and travel in and out of this province (Huang et al. 2020). They also reduced local travel and stopped schools, colleges, and universities to minimize the spread of the disease (Wilder-Smith and Freedman 2020). $\mathrm{NO}_{2}$ is a typical tracer of heavy industrial activities and air pollution correlated with premature mortality. The drop in $\mathrm{NO}_{2}$ emissions first appeared close to Wuhan but spread across the rest of the country and gradually worldwide (Vettore 2020). $\mathrm{CO}_{2}$ emissions have declined by $25 \%$ in China and $6 \%$ in the world as a further standard air pollution tracer (Dutheil et al. 2020). A similar substantial decrease in air pollution across European cities has been reported by the European Environment Agency (EEA 2020). From 16-22 March 2020, Bergamo, Italy, and Barcelona, Spain recorded a 47 and $55 \%$ decline in $\mathrm{NO}_{2}$ as compared with the same date of 2019 (Berman and Ebisu 2020). The traffic flows decreased by $60-80 \%$ in New Zealand as a result of a government-led effort to curb the virus by restricting transportation to essential services. During the period of COVID-19 lockdown, the observations suggest that $\mathrm{NO}_{2}$ has been decreased by only $34-57 \%$ and $\mathrm{BC}$ by $55-75 \%$. The $\mathrm{PM}_{2.5}$ and $\mathrm{PM}_{10}$ reduction were found significantly less (8$17 \%$ for PM2.5 and 7-20\% for PM10) (Patel et al. 2020a).

The presumption that the COVID-19 lockdown has lowered the air pollution concentrations in the troposphere and the ground level was cheeked using satellite data and a network of $>10,000$ air quality stations. The analysis shows a decrease in the population-weighted concentration of ground-level nitrogen dioxide $\left(\mathrm{NO}_{2}\right.$ : 60 percent with 95 percent CI 48 to 72 percent) and fine particulate matter ( $\mathrm{PM}_{2.5}$ : 31 percent; 95 percent CI: 17 to 45 percent), in 34 countries during the lockout period until May 15, 2020. Except ozone, tropospheric satellite measurements indicate slightly fewer spatial reductions in pollutant anomalies due to complex $\mathrm{NO}_{\mathrm{x}}$ chemistry and long-distance fine-particulate transportation with a diameter of fewer than $2.5 \mu \mathrm{m}\left(\mathrm{PM}_{2.5}\right)$ (Venter et al. 2020). Empirical results for the link between declines in global car transport and reductions in ambient $\mathrm{NO}_{2}$ exposure were established with the use of mobility data from Google and Apple. Although the global lockdown situation is not sustainable, the results draw attention to the ability to reduce risk to public health by minimizing' business as usual air pollutant emissions from economic activities. A study in major livestock provinces in northern Italy revealed that emissions of $\mathrm{NO}_{\mathrm{x}}$ and $\mathrm{PM}_{2.5}$ were reduced as their major sources, traffic and industrial activities have been halted (Lovarelli et al. 2020). However, the emission of $\mathrm{NH}_{3}$ (mainly released from the agriculture sector) was not reduced as agricultural activities were not stopped during this period (Lovarelli et al. 2020). A global analysis of emissions of greenhouse gases (GHGs) and other air pollutants revealed that global $\mathrm{NO}_{\mathrm{x}}$ reduced by $30 \%$ in April 2020 causing a short-term cooling (Forster et al. 2020). However, authors suggested that observed cooling trend is offset by a $\sim 20 \%$ decline in global $\mathrm{SO}_{2}$ emissions that reduces the aerosol cooling effect, contributing short-term warming. Therefore, authors estimated that direct effect of the outbreak-driven response will be negligible (Forster et al. 2020). Though global emissions of GHGs and other air pollutants suddenly reduced during this pandemic, a better understanding of the complex chemistry of pollutant formation is required to elucidate their impact.

It should be noted that most of the scientific literature focused on COVID-19 associated reductions in $\mathrm{NO}_{\mathrm{x}}$ and PM. There could be an imbalance of pollutants due to the reductions in $\mathrm{NO}_{\mathrm{x}}$ and $\mathrm{PM}$, while other pollutants like ozone $\left(\mathrm{O}_{3}\right)$ have received poor consideration though their concentration could vary due to changes in $\mathrm{NO}_{\mathrm{x}}$. In this context, Sharma et al. (2020) analyzed the concentration of $\mathrm{PM}_{10}, \mathrm{PM}_{2.5}, \mathrm{CO}, \mathrm{NO}_{2}, \mathrm{O}_{3}$ and $\mathrm{SO}_{2}$ in 22 cities in different regions of India between March 16 and April 14 of 20172020. Compared to the previous years, they noted a 43, 31, 10 , and $18 \%$ decline in $\mathrm{PM}_{2.5}, \mathrm{PM}_{10}, \mathrm{CO}$, and $\mathrm{NO}_{2}$, respectively. At the same time, $\mathrm{O}_{3}$ increased by $17 \%$, and $\mathrm{SO}_{2}$ improvements were negligible. In North, South, East, Central and West India, the air quality index (AQI) 
decreased by 44, 33, 28, 15 and 32\%, respectively (Sharma et al. 2020). In Hangzhou (China), Wang et al. (2020a) noted a sharp decline in the concentrations of $\mathrm{PM}_{2.5}, \mathrm{PM}_{10}, \mathrm{CO}$ and $\mathrm{NO}_{2}$ concentrations. However, concentration of $\mathrm{O}_{3}$ increased by $145 \%$ in the urban areas during the lockdown which has been correlated to its weakened titration by $\mathrm{NO}$, due to its reduced emission, during the non-photochemical reaction (Wang et al. 2020a).

Similarly, lockdown in Milan, Italy significantly increased (by a factor of 2.25) ground level $\mathrm{O}_{3}$ concentrations, while levels by $\mathrm{NO}_{2}$ were decreased by $64 \%$ (Zoran et al. 2020). Moreover, authors noted negative correlations between the total COVID-19 infections and $\mathrm{NO}_{2}$ while infections were positively correlated with ambient ground ozone levels suggesting the possible role of possibility as $\mathrm{O}_{3}$ as SARS-CoV-2 incubator (Zoran et al. 2020).

Therefore, improving air quality could have a crucial role in overcoming the pandemic. A nationwide study in the United States suggested that air pollution, particularly $\mathrm{PM}_{2.5}$, has significantly worsened the outbreak and COVID-19 death counts (Wu et al. 2020b). They found that an increase of just $1 \mu \mathrm{g} / \mathrm{m}^{3}$ in $\mathrm{PM}_{2.5}$ corresponded to an $8 \%$ increase in the COVID-19 death rate. Detection of SARS-CoV-2RNA on particulate matter $\left(\mathrm{PM}_{10}\right)$ of Bergamo in Northern Italy suggested the role of air pollution particles as vehicles for viral transmission (Setti et al. 2020). In addition to the direct role of PM as a carrier of SARS-CoV-2, Tung et al. (2020) proposed that exposure to PM indirectly increases angiotensin-converting enzyme 2 (ACE2) expression in the lungs which facilitates the adhesion of this virus. According to the European Public Health Alliance, air pollution is also known to have a negative impact on the immune system which could explain the strong correlation between air pollution and the outbreak (Vettore 2020). Therefore, tackling air pollution should constitute an important part of easing lockdown. However, further research is required to better understand the complex chemistry of air pollutant formation, transport, and temporal variability is required. Moreover, a better understanding of the role of meteorological conditions in dictating the concentration of air pollutants is required. For example, despite reduced activities, the occurrence of severe air pollution episodes has been associated with unfavorable meteorology in a modelling study in China (Wang et al. 2020b). Therefore, the role of meteorology should also be considered in designing emission control strategies.

\section{COVID-19 and agriculture sector}

COVID-19 and crop production with implications in food security: COVID-19 has a strong impact on crop production systems, supply chain, and global food security (Torero 2020). The shortage of workforce (due to restrictions on movement, and rules for social distancing) are affecting the producers, processors, and transport companies in the food supply chains (World-Bank 2020). There are reports of wastage of fresh fruits and vegetables, poultry, livestock, and dairy products due to the inability of farmers or entrepreneurs to transfer them from the production point to the local markets, supermarkets, or processing centers in the neighboring towns or cities (Yaffe-Bellany and Corkery 2020).

Global production of the most consumed grain crops (rice, wheat and maize) remained excellent. However, prices for some cash crops, a major source of income in rural areas, have been affected by the slowdown in global demand (World-Bank 2020). Moreover, the indirect effects of the epidemic on agricultural systems are visible all over the world. The massive drop in demand for restaurants and commercial food services, coupled with restrictions on employment and/or processing and storage capacity, caused farmers to abandon their mass production. Quarantine measures have greatly affected the availability of labor force reduced in the food production cycle, from growing vegetable crops to fruit harvesting, and livestock and poultry production and processing systems (Stephens et al. 2020). The time of different agricultural activities is often inflexible due to the seasonal nature of the work (Stephens et al. 2020). If farm tasks are not carried out on time, crops ready for harvest may be lost while cultivation may not be possible, which poses a challenge to future food availability. Thus, food production systems can collapse with devastating effects on global food security (FAO 2020a). With the further spread of the pandemic, these impacts are likely to be felt more widely and deeply in the national economies.

COVID-19 is massively affecting the access to food, one of the four pillars of food security. COVID-19-driven increase in poverty and declines in income would force the poor and near-poor people to switch to cheaper and less nutritious foods (Laborde et al. 2020). Countries highly dependent on exports of basic products (food, raw materials, and fuel) are affected by the significant decrease in demand in the developed world. For example, several African countries cannot export their products, so their income will continue to decline (FAO 2020c). Some countries have also imposed export restrictions limiting the market access and global agricultural trade (Laborde 2020) that will further worsen the situation.

The COVID-19 pandemic affects international relations beyond the labor force in the agricultural sector. Ports that are closed or working with limited activities have significantly reduced the cargo capacity for shipments of agricultural inputs and products, in addition to other widespread disruptions to the global supply chain due to the COVID-19 crisis (Ivanov 2020).

The existing crop production systems provide little flexibility for different crises, epidemics, and pandemics (Stephens et al. 2020). The small farms use the family workforce, and therefore are less dependent on external paid work and are more flexible than the large farms that rely on external work (Stephens et al. 2020). The task-specific farm 
machinery needs to be designed and promoted for efficiency and to reduce dependence on human labor in farming systems. New policies should be formulated to protect the farming systems from similar shocks in the future. Conservation agriculture practices and legume-based cropping systems may be promoted to reduce the overall degradation of the soil and environmental health and improve the resilience of farming systems (Cortignani and Dono 2020). The urban agriculture and home gardening can help improve the food and nutritional security during and after the COVD-19 pandemic (Lal 2020).

The movement of seasonal workers and transport companies across national and international borders may be eased down with strict compliance of safety measures and protocols. The processing industries may develop warehouse facilities, such as warehouse receipt system platforms, where farmers can deliver their products. The local fruits and vegetable markets may be shifted to larger locations while ensuring appropriate infrastructure to maintain food quality and safety (FAO 2020c).

Management of pests and diseases affecting agricultural crops is an important step towards sustaining crop production and ensuring food security. Although COVID-19 does not cause diseases in plants (Shahid and AlSadi 2020), it has on the other hand impacted efforts to manage plant diseases in different countries. Plant disease diagnosis by some extension offices has been affected (Keygrains 2020). Other effects of COVID-19 on this sector include effects on the manufacturing, export, import and application of pesticides. This indicates that the efficiency in managing plant diseases and pests will be affected, which will ultimately affect crop growth and yield. In addition, the uncertainty of whether fruits and vegetables could be surface contaminated with COVID-19 is likely to reduce the demand for fruit and vegetables (Shahid and Al-Sadi 2020).

The importance and severity of the epidemic, and its potential impact on agriculture around the world, require major repercussions. The potential risks, weaknesses and unexpected systemic changes in the food and agriculture sector should be mapped to understand the short-term and long-term or permanent effects.

\section{COVID-19 and animals}

COVID-19 is believed to be originated from a wet market in Wuhan, China dealing with live exotic animals. This lead to the speculation of a possible spill over of the virus from wild animals to human as has been the case in past epidemics such as Ebola (bush animals), MERS (camelids), SARS (civets) and Nipah (fruit bats) (Hernández et al. 2020). Similar to the MERS and SARS, the diseases caused by other corona viruses, COVID-19 has also been postulated to be transmitted from bats (Boni et al. 2020). The exact route of its transmission to humans remains elusive at this point in time. However, the possible involvement of snakes and pangolins as intermediate hosts has been speculated (Peeri et al. 2020; Zhang et al. 2020). In this context, China has banned the trade of wild animals (Zhou et al. 2020). However, researchers fear that complete bans may not work as most of the trade of wildlife is illegal and non-regulated (Zhou et al. 2020). Moreover, a complete ban on wildlife consumption is not enough (Wang et al. 2020c), but clear strategies are needed to safeguard both human health and biodiversity throughout the COVID-19 recovery (Pearson et al. 2020). It is of paramount importance to practice personnel hygiene while dealing with wildlife and regulate such markets to mitigate the risks of future pandemics. The number of people visiting natural parks was significantly reduced due to restricted movements that diminished the stress on wild fauna (Corlett et al. 2020). Wild animals have also been returned towards suburban areas, where they have not been seen for many years, as human activity and traffic declined (Corlett et al. 2020). Hence, it would also be essential to have comprehensive regulations for protecting wildlife within protected locations.

The zoonotic nature of COVID-19 is pushing researchers to look for other animal hosts that can contribute to the transmission of this disease. To date, the disease has been reported in dogs, cats, tiger, lion, and mink farms that have been living in close proximity to COVID-19 positive patients demonstrating the possibility of human to animal transmission (OIE 2020). The presence of SARS-CoV-2 in companion animals sparked fears, though unfounded, of their role in virus transmission which has led to an increase in incidents of pet abonnement and animal abuse (Parry 2020). However, dog adaptation in Israel has increased significantly as interactions with animals may help with stress and depression particularly in social isolation (Morgan et al. 2020). There is currently no evidence of SARS-CoV-2 transmission from pets to humans. However, future studies will further ameliorate our understanding of this transmission. Under controlled conditions, it has been found that cats can infect other cats through respiratory transmission (Shi et al. 2020). Dogs are weakly positive while pigs and poultry including chicken, duck, geese and quail demonstrated to be resistant (Shi et al. 2020; Suarez et al. 2020). Although, SARS-CoV-2 isolated from dogs and cats has an identical sequence of $\mathrm{S}$ protein, their role as a reservoir for the animal to human transmission remains elusive (Hernández et al. 2020).

In addition to the effects on wild and pet animals, the livestock industry has also suffered like other industries during this pandemic. Multiple clusters of COVID-19 emerged in slaughterhouse workers in Brazil, Germany, the USA, France resulting in scores of infections and deaths (DW-News 2020; Kinniburgh 2020). The presence of multiple hotspots resulted in temporary closures or reduced efficiency of many slaughterhouses worldwide disrupting the supply chain. These slaughterhouse shutdowns have also forced the on-farm killing of animals (Kevany 2020). Careful estimates reveal that more than 10 million pigs and poultry each will be culled or depopulated by September in the US 
alone (Kevany 2020). This large-scale culling can be challenging and can have environmental consequences especially in times when hunger in the world is on the rise. Spike in cases in China, that too associated with animals, forced them to ban the import of meat from Tyson company, the largest America-based meat processing company (Funk 2020). These developments can have serious economic consequences in the livestock industry. Additionally, about $30 \%$ of staff shortage in France was inflicted directly or indirectly due to COVID-19 (FAO 2020b).

Uninterrupted supply of nutrition to animals remains the key factor for the smooth running of animal protein farms. Restriction of movements to contain this pandemic may have negatively affected the provision of certain nutritional elements particularly of those transported across the borders (Seleiman et al. 2020). However, the major impact may be the disruption in the supply chain of dairy products to end consumers. When the US imposed a lockdown, the people rushed to the stores for hoarding of edibles including dairy products that resulted in their shortage at various stores. On the other hand, the closure of schools and restaurants decreased the demand for dairy products (Mulvey et al. 2020). During the pandemic, production remains high, but the industry is unable to process all the milk and farmers are forced to dump millions of gallons of milk in a time when people are dying of hunger (Townley 2020). However, recent trends showed that people are shifting to farms having direct access to consumers to purchase dairy products (Mulvey et al. 2020). Misinformation is another challenge for the farmers as that may shake consumer's confidence in animal proteins. Recently, the circulation of news on social media about the association of SARS-CoV-2 with poultry in India has significantly slashed the demand and price of poultry meat (Gupte 2020). Therefore, better supply management, financial assistance to farmers, and control of misinformation will be required to protect the livestock industry from further shocks.

The last two decades have witnessed SARS, MERS, and COVID-19 which have been caused by other corona viruses. Therefore, another future outbreak caused by another corona virus cannot be ruled out. Thus, to better protect human health and food biosafety and biosecurity due to COVID-19, the multidisciplinary approach under the ambit of one health is called for. It is worth mentioning that COVID-19 inflicted lockdown allows us to better understand the impacts of humans on wildlife which may help in better coexistence of wildlife and human (Rutz et al. 2020). Massive deforestation and change in ecosystems may change human interactions with wildlife that could potentiate emerging zoonosis in humans (Fawzi et al. 2020).

\section{COVID-19 and energy sector}

COVID-19 has severely affected the energy sector. Energy is the key to health care services and matters more than ever during the pandemic time ( Broto and Kirshner 2020). Health facilities have two main energy requirements: electrical energy for medical equipment and health services including refrigeration, thermal requirements for sterilization, water heating, and incineration. Many countries have taken intense measures most notably social distancing and lockdowns of public life that led to a reduction in industrial activity, mobility, and energy consumption. The reduction in global oil demand reduced the price and production of oil. According to the Oil Market Report - July 2020 released by International Energy Agency (IEA), global oil demand fell by $9.3 \mathrm{mb} / \mathrm{d}$ year-on-year in 2020 due to the lockdowns while global oil supply fell by $2.4 \mathrm{mb} / \mathrm{d}$ in June, to a nineyear low of $86.9 \mathrm{mb} / \mathrm{d}$ (IEA 2020b). This disruption in oil demand and supply has a major effect on the oil-producing countries. There was also a global reduction in electrical energy demand and price in some counties (Mastropietro et al. 2020). Analysis of daily data through mid-April, reported in Global Energy Review 2020 by IEA, revealed that countries in full lockdown experienced an average $25 \%$ decline in energy demand per week and countries in partial lockdown an average 18\% decline (IEA 2020a). During this pandemic, total energy plunged due to a decline in industrial and commercial activities while domestic consumption of electricity increased due to a larger occupancy (Mastropietro et al. 2020). Electricity consumption declined by $25 \%$ in Italy, 20\% in France, and 12\% in the UK (Mylenka 2020). Amid COVID-19 at its peak in 16 European countries, electricity demand was reduced by $19 \%$ which resulted in a significant drop in carbon emissions by $34 \%$ (Haxhimusa and Liebensteiner 2020). Similarly, the delay or nonpayment of utility bills by end-consumers affected the distribution, transmission and generation companies. Moreover, lockdowns have delayed the power projects by disruptions in the supply chain and machinery, unavailability of manpower, and reductions in project financing. It has been noted in the latest World Energy Investment report by IEA that investments in energy are set to fall by one-fifth in 2020 due to COVID-19 (IEA 2020c). Considering the dependence of the global economy on the energy sector, COVID-19 has severely affected this sector causing widespread and drastic effects on the demand, supply, energy prices and investments in the energy sector.

All countries should consider energy as a basic human right due to its central role in responding to pandemics by ensuring adequate healthcare services and supporting households during confinement ( Broto and Kirshner 2020). Energy access is also recognized in Sustainable Development Goals (SDG) as SDG 7 commits to ensuring "access to affordable, reliable, sustainable, and modern energy for all. Independent and reliable access to energy would be essential to maintain health under pandemics such as COVID-19 ( Broto and Kirshner 2020). Therefore, the provision of energy relief is called for the growing number of households that are energy insecure (Graff and Carley 2020) which should be based on proper targeting and consistent financing (Mastropietro et al. 2020). Moreover, it is 
recommended for the governments to seek their supplies from more than one country to avoid delay in energy projects during future global crises.

The renewable energy section is not immune to this outbreak and has been negatively affected due to delays in power plant equipment delivery or in the construction work. The spread of the virus has caused the shutdowns of several industries and issues along the supply chain across multiple industry sectors. Contractors reliant on an international workforce are also impacted by labor shortages due to travel restrictions or quarantine measures. Project developers may be facing penalties or, in some cases, losing tax incentives, tariffs, or other revenue sources. For example, BYD, producer for rechargeable batteries, was unable to complete the required testing for some batteries which led to a delay in delivering the required quantities of these batteries for the European market (Mylenka 2020).

The major global concern of the renewable energy sector is the supply chain issues with solar and wind projects already witnessing logistical delays. Furthermore, governments, in developing countries, are the big buyers for renewable energy products, but because of the virus, the available funds are diverted for medical purposes which further has a negative impact on renewable energy projects ( Broto and Kirshner 2020). Despite this, it has been suggested by the industry reports renewable energy industry is expected to grow while fossil oil-based industries will likely struggle financially (Penn 2020). Gillingham et al. (2020) suggested that pushing back all investments for renewable electricity production by one year would outweigh the emissions reductions observed due to the lockdowns. Therefore, both the International Energy Agency (Birol 2020) and the International Renewable Energy Agency (Camera 2020) have suggested maintaining necessary investments into renewable energy in the wake of COVID-19. Developed countries should continue to invest in developing communities in support of clean and renewable energy. Investing in renewables and energy efficiency must help to create green jobs to get political traction (Hanna et al. 2020). The advantages of renewable energy have become particularly evident during the pandemic and therefore suitable investments to restart the economy should be dedicated to cleaner and sustainable energy infrastructure. Despite significant reductions in GHGs emissions, their net effect on climate change is almost negligible as effects of NOx reductions are offset by reductions in $\mathrm{SO}_{2}$ emissions (Forster et al. 2020). In contrast, Forster et al. (2020) suggested that "an economic recovery tilted towards green stimulus and reductions in fossil fuel investments, it is possible to avoid future warming of $0.3^{\circ} \mathrm{C}$ by $2050^{\prime \prime}$.

\section{Conclusion and Next Steps}

COVID-19 has upended the world in few months with widespread shutdowns and major changes in the economy, life style, and environment. Short-term improvements in the quality of air and water resources have been observed. The existence of SARS-CoV-2 in wastewater has enabled researchers in many countries to track the prevalence of COVID-19 infections in the community that can be particularly helpful for communities with limited facilities of clinical analyses. Wastewater-based epidemiology, being an emerging field to monitor COVID-19, needs to optimize the sampling protocols, develop laboratory analysis methods and ensure quality control for international locations. The presence of this virus in wastewater raised environmental risks about its faecal-oral transmission which, yet hypothetical for SARS-CoV-2, has been noted in many viral diseases like E-bola and hepatitis (E \& A). Considering these risks, wastewater disinfection has gained significant attention from the scientific community. In this context, it would be highly rewarding to develop robust and cost-effective techniques particularly for emergency situations. Existence of SARS-CoV-2 in wastewater may also lead to its aerosolization during wastewater treatment and sprinkler irrigation for agricultural purposes. Therefore, it would be essential to exercise precautions and raise public awareness to ensure the safe use of wastewater in agriculture. Similarly, increased use of antimicrobials can be an emerging environmental threat associated with this pandemic which should not be ignored. Air quality has also been improved as evident from reductions in $\mathrm{NO}_{\mathrm{X}}, \mathrm{SO}_{\mathrm{X}}$ and $\mathrm{PM}$. Despite significant reductions in GHGs emissions, effect on climate change might be negligible due to the complex chemistry of air pollution (effects of NOx reductions can be offset by decline in $\mathrm{SO}_{2}$ ). Moreover, a decrease in the concentration of these pollutants may increase the contents of $\mathrm{O}_{3}$ by pollutant imbalance. The role of $\mathrm{PM}$ and $\mathrm{O}_{3}$ as carriers for SARS$\mathrm{CoV}-2$ suggested that an increase in air pollution could significantly worsen the outbreak. Therefore, tackling air pollution should constitute an important part of easing lockdown. However, further research is required to explore the complex chemistry of air pollutant formation, transport, and temporal variability.

COVID-19 has also highlighted the urgent necessity of ensuring strict bans on the illegal trade of wildlife. Necessary funds should be maintained to monitor zoonosis with a focus on all potential routes for zoonotic transfer. The COVID-19 pandemic has significantly affected the crop and food production systems and has challenged global food security. The shortage of workforce and disruptions in the supply chain had been noted as the major challenges. Designing the smart farm machinery and policy formulation, to protect the farming systems from similar shocks in the future, may help cope with the challenges. Diversification of cropping systems and promotion of conservation agriculture practices and home gardening may help improve the food and nutritional security during and after the COVD-19 pandemic. Similarly, global reductions in the demand for electricity and fuel and halted investments in energy has severely affected this sector. However, the advantages of renewable energy have become particularly evident and therefore, suitable 
investments into cleaner and sustainable energy infrastructure are called for in plans to revive the global economy after this crisis. Tilting the economic recovery towards green stimulus and lower investments in fossil fuels could contribute to avoiding the future warming associated with climate change. Undoubtedly, the major focus of most developed countries is to improve their health system. However, a pandemic of this intensity needs international cooperation and thus adequate interventions are needed in the developing communities to prevent their becoming population reservoirs for such viruses.

\section{Conflict of Interest}

Authors declare no competing interests.

\section{Author Contributions}

M. Usman: Conceptualization, Original draft preparation, review and editing; M. Farooq (1): Original draft preparation, review and editing; S. Jellali: Original draft preparation, review and wditing; M. Farooq (2): Original draft preparation, review and editing; Y. Charabi: Original draft preparation, review and editing; A.M. Al-Sadi: Original draft preparation, review and editing; A. Al-Badi: Original draft preparation, review and editing.

\section{References}

Ahmed W, N Angel, J Edson, K Bibby, A Bivins, JW O'Brien, PM Choi, M Kitajima, SL Simpson, J Li, B Tscharke, R Verhagen, WJM Smith, J Zaugg, L Dierens, P Hugenholtz, KV Thomas, JF Mueller (2020). First confirmed detection of SARS-CoV-2 in untreated wastewater in Australia: A proof of concept for the wastewater surveillance of COVID-19 in the community. Sci Total Environ 728; Article 138764

Berman JD, K Ebisu (2020). Changes in U.S. air pollution during the COVID-19 pandemic. Sci Total Environ 739; Article 139864

Birol F (2020). The coronavirus crisis reminds us that electricity is more indispensable than ever, pp:1-1. Internationl Energy Agency, https://www.iea.org/commentaries/the-coronavirus-crisis-reminds-usthat-electricity-is-more-indispensable-than-ever

Bivins A, D North, A Ahmad, W Ahmed, E Alm, F Been, P Bhattacharya, L Bijlsma, AB Boehm, J Brown, G Buttiglieri, V Calabro, A Carducci, S Castiglioni, ZC Gurol, S Chakraborty, F Costa, S Curcio, FLDL Reyes, JD Vela, K Farkas, X Fernandez-Casi, C Gerba, D Gerrity, R Girones, R Gonzalez, E Haramoto, A Harris, PA Holden, MT Islam, DL Jones, B Kasprzyk-Hordern, M Kitajima, N Kotlarz, M Kumar, K Kuroda, GL Rosa, F Malpei, M Mautus, SL McLellan, G Medema, JS Meschke, J Mueller, RJ Newton, D Nilsson, RT Noble, A van Nuijs, J Peccia, TA Perkins, AJ Pickering, J Rose, G Sanchez, A Smith, L Stadler, C Stauber, K Thomas, T van der Voorn, K Wigginton, K Zhu, K Bibby (2020). WastewaterBased Epidemiology: Global Collaborative to Maximize Contributions in the Fight Against COVID-19. Environ Sci Technol 54:7754-7757

Bogler A, A Packman, A Furman, A Gross, A Kushmaro, A Ronen, C Dagot, C Hill, D Vaizel-Ohayon, E Morgenroth, E Bertuzzo, G Wells, HR Kiperwas, H Horn, I Negev, I Zucker, I Bar-Or, J Moran-Gilad, JL Balcazar, K Bibby, M Elimelech, N Weisbrod, O Nir, O Sued, O Gillor, PJ Alvarez, S Crameri, S Arnon, S Walker, S Yaron, TH Nguyen, Y Berchenko, Y Hu, Z Ronen, E Bar-Zeev (2020). Rethinking wastewater risks and monitoring in light of the COVID-19 pandemic. Nat Sustain 3:981-990
Boni MF, P Lemey, X Jiang, TTY Lam, BW Perry, TA Castoe, A Rambaut, DL Robertson (2020). Evolutionary origins of the SARS-CoV-2 sarbecovirus lineage responsible for the COVID-19 pandemic. Nat Microbiol 5:1408-1417

Braga F, GM Scarpa, VE Brando, G Manfè, L Zaggia (2020). COVID-19 lockdown measures reveal human impact on water transparency in the Venice Lagoon. Sci Total Environ 736; Article 139612

Broto VC, J Kirshner (2020). Energy access is needed to maintain health during pandemics. Nat Ener 5:419-421

Burnett R, H Chen, M Szyszkowicz, N Fann, B Hubbell, CA Pope, JS Apte, M Brauer, A Cohen, S Weichenthal, J Coggins, Q Di, B Brunekreef, J Frostad, SS Lim, H Kan, KD Walker, GD Thurston, RB Hayes, CC Lim, MC Turner, M Jerrett, D Krewski, SM Gapstur, WR Diver, B Ostro, D Goldberg, DL Crouse, RV Martin, P Peters, L Pinault, M Tjepkema, AV Donkelaar, PJ Villeneuve, AB Miller, P Yin, M Zhou, L Wang, NAH Janssen, M Marra, RW Atkinson, H Tsang, T Quoc Thach, JB Cannon, RT Allen, JE Hart, F Laden, G Cesaroni, F Forastiere, G Weinmayr, A Jaensch, G Nagel, H Concin, JV Spadaro (2018). Global estimates of mortality associated with long-term exposure to outdoor fine particulate matter. Proc Natl Acad Sci 115:9592-9597

Cahill N, D Morris (2020). Recreational waters - A potential transmission route for SARS-CoV-2 to humans? Sci Total Environ 740; Article 140122

Camera FL (2020). Staying on course: renewable energy in the time of COVID-19. International Renewable Energy Agency https://www.irena.org/newsroom/pressreleases/2020/Apr/Staying-onCourse-Renewable-Energy-in-the-time-of-COVID19

Corlett RT, RB Primack, V Devictor, B Maas, VR Goswami, AE Bates, LP Koh, TJ Regan, R Loyola, RJ Pakeman, GS Cumming, A Pidgeon, D Johns, R Roth (2020). Impacts of the coronavirus pandemic on biodiversity conservation. Biol Conserv 246; Article 108571

Cortignani R, G Dono (2020). Greening and legume-supported crop rotations: An impacts assessment on Italian arable farms. Sci Total Environ 734; Article 139464

Dutheil F, JS Baker, V Navel (2020). COVID-19 as a factor influencing air pollution? Environ Pollut 263; Article 114466

DW-News (2020). Coronavirus: Over 600 people test positive at German slaughterhouse. https://www.dw.com/en/coronavirus-over-600people-test-positive-at-german-slaughterhouse/a-53846038

EEA (2020). Air pollution goes down as Europe takes hard measures to combat coronavirus. NASA Earth Observatory https://www.eea.europa.eu/highlights/air-pollution-goes-down-as (accessed August 07, 2020)

FAO (2020a). FAO recommendations on planting and harvesting tasks during the COVID-19 outbreak using crop calendars. http://wwwfaoorg/2019-ncov/covid-19-crop-calendars/en/ (Accessed August 06, 2020)

FAO (2020b). Mitigating the impacts of COVID-19 on the livestock sector. http://www.fao.org/documents/card/en/c/ca8799en/ (Accessed July $15,2020)$

FAO (2020c). Q\&A: COVID-19 pandemic - impact on food and agriculture. http://wwwfaoorg/2019-ncov/q-and-a/impact-on-food-andagriculture/en/ (Accessed on August 06, 2020)

Fawzi NI, IZ Qurani, AN Rahmasary, M Sihombing (2020). Covid-19: A Zoonosis Related to Deforestation and Foodborne Disease. Figshare https://doi.org/10.6084/m9.figshare.12331493.v2

Forster PM, HI Forster, MJ Evans, MJ Gidden, CD Jones, CA Keller, RD Lamboll, CL Quéré, J Rogelj, D Rosen, CF Schleussner, TB Richardson, CJ Smith, ST Turnock (2020). Current and future global climate impacts resulting from COVID-19. Nat Clim Change 10:913-919

Funk J (2020). US Meat Industry Puzzled by China's Import Ban for 1 Plant. The Associated Press https: //apnews.com/ 93a476af6c3d2e04c0ac0ad0c03c0f54 (Accessed June 23, 2020)

Gillingham KT, CR Knittel, J Li, M Ovaere, M Reguant (2020). The shortrun and long-run effects of Covid-19 on energy and the environment. Joule 4:1337-1341

Graff M, S Carley (2020). COVID-19 assistance needs to target energy insecurity. Nat Ener 5:352-354 
Guerrero-Latorre L, I Ballesteros, I Villacrés-Granda, MG Granda, B FreirePaspuel, B Ríos-Touma (2020). SARS-CoV-2 in river water: Implications in low sanitation countries. Sci Total Environ 743; Article 140832

Gupte A (2020). Coronavirus rumours cost India's poultry dearly. Poultry World https://www.poultryworld.net/Meat/Articles/2020/6/Coronavirusrumours-cost-Indias-poultry-dearly-600561E/ (Accessed on July 01)

Hallema DW, FN Robinne, SG McNulty (2020). Pandemic spotlight on urban water quality. Ecol Process 9:22-24

Hanna R, Y Xu, DG Victor (2020). After COVID-19, green investment must deliver jobs to get political traction. Nature 582:178-180

Haxhimusa A, M Liebensteiner (2020). Effect of COVID-19 on Power Sector Emissions. https://www.fhgrch/fileadmin/fhgr/lebensraum/ZWF/ Publikationen/Haxhimusa_Liebensteiner_2020_Covid-19.pdf (Accessed April 29, 2020)

Hernández M, D Abad, JM Eiros, D Rodríguez-Lázaro (2020). Are animals a neglected transmission route of SARS-CoV-2? Pathogens 9; Article 480

Huang C, Y Wang, X Li, L Ren, J Zhao, Y Hu, L Zhang, G Fan, J Xu, X Gu, Z Cheng, T Yu, J Xia, Y Wei, W Wu, X Xie, W Yin, H Li, M Liu, Y Xiao, H Gao, L Guo, J Xie, G Wang, R Jiang, Z Gao, Q Jin, J Wang, B Cao (2020). Clinical features of patients infected with 2019 novel coronavirus in Wuhan, China. Lancet 395:497-506

Huraimel K, M Alhosani, S Kunhabdulla, MH Stietiya (2020). SARS-CoV-2 in the environment: Modes of transmission, early detection and potential role of pollutions. Sci Total Environ 744; Article 140946

IEA (2020a). Global Energy Review 2020: The impacts of the Covid-19 crisis on global energy demand and $\mathrm{CO}_{2}$ emissions. International Energy Agency https://www.iea.org/reports/global-energy-review2020 (Accessed April 2020)

IEA (2020b). Oil Market Report - July 2020. International Energy Agency https://www.iea.org/reports/oil-market-report-july-2020

IEA (2020c). World Energy Investment 2020. International Energt Agency https://www.iea.org/reports/world-energy-investment-2020\# (Accessed May 2020)

Ivanov D (2020). Predicting the impacts of epidemic outbreaks on global supply chains: A simulation-based analysis on the coronavirus outbreak (COVID-19/SARS-CoV-2) case. Transp Res E Logist Transp Rev 136; Article 101922

Kalbusch A, E Henning, MP Brikalski, FVD Luca, AC Konrath (2020). Impact of coronavirus (COVID-19) spread-prevention actions on urban water consumption. Resour Conserv Recycl 163; Article 105098

Kevany S (2020). Millions of US farm animals to be culled by suffocation, drowning and shooting. The Guardian. Available at: https://www.theguardian.com/environment/2020/may/19/millions-ofus-farm-animals-to-be-culled-by-suffocation-drowning-and-shootingcoronavirus (Accessed July 02, 2020)

Keygrains (2020). Plans for Plant Disease Diagnosis During the COVID-19 Threat https://www.kygrains.info/blog/2020/4/2/plans-for-plantdisease-diagnosis-during-the-covid-19-threat (Accessed August 07, 2020)

Kinniburgh C (2020). COVID-19: How the meat industry became a global health liability, France 24 https://www.france24.com/en/20200524covid-19-how-the-meat-industry-became-a-global-health-liability (Accessed August 06, 2020)

Kitajima M, W Ahmed, K Bibby, A Carducci, CP Gerba, KA Hamilton, E Haramoto, JB Rose (2020). SARS-CoV-2 in wastewater: State of the knowledge and research needs. Sci Total Environ 739; Article 139076

Kümmerer K, DD Dionysiou, O Olsson, D Fatta-Kassinos (2018). A path to clean water. Science 361:222-224

Laborde D (2020). Food Export Restrictions during the Covid-19 crisis. International Food Plicy Research Institute, Washington, DC, USA https://public.tableau.com/profile/laborde6680\#!/vizhome/ExportRest rictionsTracker/FoodExportRestrictionsTracker (Accessed June 10, 2020)

Laborde D, W Martin, J Swinnen, R Vos (2020). COVID-19 risks to global food security. Science 369:500-502

Lal R (2020). Home gardening and urban agriculture for advancing food and nutritional security in response to the COVID-19 pandemic. Food Sec $12: 871-876$
Lodder W, AMDR Husman (2020). SARS-CoV-2 in wastewater: potential health risk, but also data source. Lanc Gastroenterol Hepatol 5:533-534

Lovarelli D, C Conti, A Finzi, J Bacenetti, M Guarino (2020). Describing the trend of ammonia, particulate matter and nitrogen oxides: The role of livestock activities in northern Italy during Covid-19 quarantine. Environ Res 191; Article 110048

Luan X, X Liu, C Fang, W Chu, Z Xu (2020). Ecotoxicological effects of disinfected wastewater effluents: a short review of in vivo toxicity bioassays on aquatic organisms. Environ Sci Water Res Technol 6:2275-2286

Mandal I, S Pal (2020). COVID-19 pandemic persuaded lockdown effects on environment over stone quarrying and crushing areas. Sci Total Environ 732; Article 139281

Mastropietro P, P Rodilla, C Batlle (2020). Emergency measures to protect energy consumers during the Covid-19 pandemic: A global review and critical analysis. Energy Res Soc Sci 68; Article 101678

McNamara PJ, TM LaPara, PJ Novak (2014). The impacts of triclosan on anaerobic community structures, function, and antimicrobial resistance. Environ Sci Technol 48:7393-7400

Medema G, L Heijnen, G Elsinga, R Italiaander, A Brouwer (2020). Presence of SARS-Coronavirus-2 RNA in sewage and correlation with reported COVID-19 prevalence in the early stage of the epidemic in The Netherlands. Environ Sci Technol Lett 7:511-516

Morgan L, A Protopopova, RID Birkler, B Itin-Shwartz, GA Sutton, B Yakobson, T Raz (2020). Human-dog relationships during COVID19 pandemic; booming dog adoption during social isolation. Hum Soc Sci Commun 7:1-11https://doi.org/10.31235/osf.io/s9k4y

Mulvey C, R Peters, N Rutkowski (2020). Impacts of COVID-19 on the US Dairy Industry. https://digitalcommonswpiedu/iqp-all/5751

Mylenka T (2020). Impact of Covid-19 on the global energy sector. PV Magazine. Available at: https://www.pvmagazine.com/2020/04/24/impact-of-covid-19-on-the-global-energysector/ (Access: April 24, 2020)

O'Reilly KM, DJ Allen, P Fine, H Asghar (2020). The challenges of informative wastewater sampling for SARS-CoV-2 must be met lessons from polio eradication. Lanc Microb 1:e189-e190

OIE (2020). World Organisation for Animal Health. COVID-19 portal: Questions and Answers on COVID-19. https://www.oie.int/scientificexpertise/specific-information-and-recommendations/questions-andanswers-on-2019novel-coronavirus/

Parry NMA (2020). COVID-19 and pets: When pandemic meets panic Forens Sci Intl Rep 2; Article 100090

Patel M, R Kumar, K Kishor, T Mlsna, CU Pittman, D Mohan (2019). Pharmaceuticals of emerging concern in aquatic systems: Chemistry, occurrence, effects, and removal methods. Chem Rev 119:3510-3673

Patel H, N Talbot, J Salmond, K Dirks, S Xie, P Davy (2020a). Implications for air quality management of changes in air quality during lockdown in Auckland (New Zealand) in response to the 2020 SARS-CoV-2 epidemic. Sci Total Environ 746; Article 141129

Patel PP, S Mondal, KG Ghosh (2020b). Some respite for India's dirtiest river? Examining the Yamuna's water quality at Delhi during the COVID-19 lockdown period. Sci Total Environ 744; Article 140851

Patni K, MK Jindal (2020). A positive perspective during COVID-19 related to groundwater crisis. Groundw Sustain Dev 11; Article 100420

Pearson RM, M Sievers, EC McClure, MP Turschwell, RM Connolly (2020). COVID-19 recovery can benefit biodiversity. Science 368:838-839

Peeri NC, N Shrestha, MS Rahman, R Zaki, Z Tan, S Bibi, M Baghbanzadeh, N Aghamohammadi, W Zhang, U Haque (2020). The SARS, MERS and novel coronavirus (COVID-19) epidemics, the newest and biggest global health threats: what lessons have we learned? Intl J Epidemiol 49:717-726

Penn I (2020). Oil companies are collapsing, but wind and solar energy keep growing. The New York Times https://www.nytimes.com/ 2020/04/07/business/energy-environment/coronavirus-oil-wind-solarenergy.html (Accessed April 07, 2020)

Quilliam RS, M Weidmann, V Moresco, H Purshouse, Z O'Hara, DM Oliver (2020). COVID-19: The environmental implications of shedding SARS-CoV-2 in human faeces. Environ Intl 140; Article 105790 
Race M, A Ferraro, E Galdiero, M Guida, A Núñez-Delgado, F Pirozzi, A Siciliano, M Fabbricino (2020). Current emerging SARS-CoV-2 pandemic: Potential direct/indirect negative impacts of virus persistence and related therapeutic drugs on the aquatic compartments. Environ Res 188; Article 109808

Rawson TM, D Ming, R Ahmad, LSP Moore, AH Holmes (2020a). Antimicrobial use, drug-resistant infections and COVID-19. Nat Rev Microbiol 18:409-410

Rawson TM, LSP Moore, N Zhu, N Ranganathan, K Skolimowska, M Gilchrist, G Satta, G Cooke, A Holmes (2020b). Bacterial and fungal co-infection in individuals with coronavirus: A rapid review to support COVID-19 antimicrobial prescribing. Clin Infect Dis 71:2459-2468

Rosa GL, M Iaconelli, P Mancini, GB Ferraro, C Veneri, L Bonadonna, L Lucentini, E Suffredini (2020). First detection of SARS-CoV-2 in untreated wastewaters in Italy. Sci Total Environ 736; Article 139652

Rutz C, MC Loretto, AE Bates, SC Davidson, CM Duarte, W Jetz, M Johnson, A Kato, R Kays, T Mueller, RB Primack, Y Ropert-Coudert, MA Tucker, M Wikelski, F Cagnacci (2020). COVID-19 lockdown allows researchers to quantify the effects of human activity on wildlife. Nat Ecol Evol 4:1156-1159

Seleiman MF, S Selim, BA Alhammad, BM Alharbi, FC Juliatti (2020). Will novel coronavirus (Covid-19) pandemic impact agriculture, food security and animal sectors? Biosci J 36:1315-1326

Selvam S, K Jesuraja, S Venkatramanan, SY Chung, PD Roy, P Muthukumar, M Kumar (2020). Imprints of pandemic lockdown on subsurface water quality in the coastal industrial city of Tuticorin, South India: A revival perspective. Sci Total Environ 738; Article 139848

Setti L, F Passarini, GD Gennaro, P Barbieri, MG Perrone, M Borelli, J Palmisani, AD Gilio, V Torboli, F Fontana, L Clemente, A Pallavicini, M Ruscio, P Piscitelli, A Miani (2020). SARS-Cov2RNA found on particulate matter of Bergamo in Northern Italy: First evidence. Environ Res 188; Article 109754

Shahid MS, AM Al-Sadi (2020). Can fruits and vegetables be infected on contaminated by Covid-19? Intl J Nutr Pharmacol Neurol Dis 10:157-158

Sharma S, M Zhang, Anshika, J Gao, H Zhang, SH Kota (2020). Effect of restricted emissions during COVID-19 on air quality in India. $S c i$ Total Environ 728; Article 138878

Shi J, Z Wen, G Zhong, H Yang, C Wang, B Huang, R Liu, X He, L Shuai, Z Sun (2020). Susceptibility of ferrets, cats, dogs, and other domesticated animals to SARS-coronavirus 2. Science 368:1016-1020

Stephens EC, G Martin, MV Wijk, J Timsina, V Snow (2020). Editorial: Impacts of COVID-19 on agricultural and food systems worldwide and on progress to the sustainable development goals. Agric Sys 183; Article 102873

Suarez DL, MJ Pantin-Jackwood, DE Swayne, SA Lee, SM Deblois, E Spackman (2020). Lack of susceptibility of poultry to SARS-CoV-2 and MERS-CoV. BioRxiv 20201-6

Torero M (2020). Without food, there can be no exit from the pandemic. Nature 580:588-589

Townley E (2020). Dairy farmers are dumping millions of gallons of milk. This could make it stop. CNN https://edition.cnn.com/2020/06/08 /perspectives/cabot-dairy-farmers-pandemic/index.html (Accessed June 15, 2020)

Tung NT, PC Cheng, KH Chi, T-C Hsiao, T Jones, K BéruBé, KF Ho, HC Chuang (2020). Particulate matter and SARS-CoV-2: A possible model of COVID-19 transmission. Sci Total Environ 750; Article 141532

Usman M, M Farooq, M Farooq, I Anastopoulos (2021). Exposure to SARS$\mathrm{CoV}-2$ in aerosolized wastewater: toilet flushing, wastewater treatment, and sprinkler irrigation. Water 13:436-441

Usman M, M Farooq, K Hanna (2020a). Environmental side effects of the injudicious use of antimicrobials in the era of COVID-19. Sci Total Environ 745; Article 141053

Usman M, M Farooq, K Hanna (2020b). Existence of SARS-CoV-2 in wastewater: implications for its environmental transmission in developing communities. Environ Sci Technol 54:7758-7759
Venter ZS, K Aunan, S Chowdhury, J Lelieveld (2020). COVID-19 lockdowns cause global air pollution declines. Proc Natl Acad Sci 117:18984-18990

Vasel-Be-Hagh A, DS Ting (2020). Environmental Management of Air Water, Agriculture, and Energy. CRC Press, Boca Raton, Florida, USA

Vettore G (2020). Air pollution and damages to immunity. https://epha.org/ air-pollution-and-damages-to-immunity/ (Accessed August 07, 2020)

Viglione G (2020). As lockdowns lift, new hazards lurk in the water. Nature doi: 10.1038/d41586-020-01286-9

Wang L, M Li, S Yu, X Chen, Z Li, Y Zhang, L Jiang, Y Xia, J Li, W Liu, P Li, E Lichtfouse, D Rosenfeld, JH Seinfeld (2020a). Unexpected rise of ozone in urban and rural areas, and sulfur dioxide in rural areas during the coronavirus city lockdown in Hangzhou, China: implications for air quality. Environ Chem Lett 18:1713-1723

Wang P, K Chen, S Zhu, P Wang, H Zhang (2020b). Severe air pollution events not avoided by reduced anthropogenic activities during COVID-19 outbreak. Resour Conserv Recycl 158; Article 104814

Wang H, J Shao, X Luo, Z Chuai, S Xu, M Geng, Z Gao (2020c). Wildlife consumption ban is insufficient. Science 367:1435-1435

Westhaus S, FA Weber, S Schiwy, V Linnemann, M Brinkmann, M Widera, C Greve, A Janke, H Hollert, T Wintgens, S Ciesek (2021). Detection of SARS-CoV-2 in raw and treated wastewater in Germany Suitability for COVID-19 surveillance and potential transmission risks. Sci Total Environ 751; Article 141750

WHO (2020). WHO Director-General's opening remarks at the media briefing on COVID-19 - 27 July 2020. World Health Organization https://www.who.int/dg/speeches/detail/who-director-general-sopening-remarks-at-the-media-briefing-on-covid-19---27-july-2020 (Accessed: July 27, 2020)

Wilder-Smith A, DO Freedman (2020). Isolation, quarantine, social distancing and community containment: pivotal role for old-style public health measures in the novel coronavirus (2019-nCoV) outbreak. J Travel Med 27:1-4

World-Bank (2020). Food Security and COVID-19. https://www.worldbank.org/en/topic/agriculture/brief/food-securityand-covid-19 (Accessed August 07, 2020)

Worldometers (2020). Coronavirus Updates. https://www.worldometers.info/ coronavirus/ (Accessed February 11, 2020)

Wu F, A Xiao, J Zhang, X Gu, WL Lee, K Kauffman, W Hanage, M Matus, N Ghaeli, N Endo, C Duvallet, M Poyet, K Moniz, AD Washburne, TB Erickson, PR Chai, J Thompson, EJ Alm (2020a). SARS-CoV-2 titers in wastewater are higher than expected from clinically confirmed cases. msytems 5:1-9

Wu X, RC Nethery, BM Sabath, D Braun, F Dominici (2020b). Air pollution and COVID-19 mortality in the United States: Strengths and limitations of an ecological regression analysis. Sci $A d v$ 6; Article eabd4049

Wurtzer S, V Marechal, JM Mouchel, L Moulin (2020). Time course quantitative detection of SARS-CoV-2 in Parisian wastewaters correlates with COVID-19 confirmed cases. MedRxiv 2020:1-13

Yaffe-Bellany D, M Corkery (2020). Dumped milk, smashed eggs, plowed vegetables: Food waste of the pandemic. The New York Times. https://www.nytimes.com/2020/04/11/business/coronavirusdestroying-food.html (Accessed: August 07, 2020)

Yunus AP, Y Masago, Y Hijioka (2020). COVID-19 and surface water quality: Improved lake water quality during the lockdown. Sci Total Environ 731; Article 139012

Zaneti RN, V Girardi, FR Spilki, K Mena, APC Westphalen, ERD Costa Colares, AG Pozzebon, RG Etchepare (2021). Quantitative microbial risk assessment of SARS-CoV-2 for workers in wastewater treatment plants. Sci Total Environ 754; Article 142163

Zhang T, Q Wu, Z Zhang (2020). Probable pangolin origin of SARS-CoV-2 associated with the COVID-19 outbreak. Curr Biol 30:1346-1351

Zhou ZM, CD Buesching, DW Macdonald, C Newman (2020). China: clamp down on violations of wildlife trade ban. Nature 578:217

Zoran MA, RS Savastru, DM Savastru, MN Tautan (2020). Assessing the relationship between ground levels of ozone $\left(\mathrm{O}_{3}\right)$ and nitrogen dioxide $\left(\mathrm{NO}_{2}\right)$ with coronavirus (COVID-19) in Milan, Italy. Sci Total Environ 740; Article 140005 